\section{International Scientific Journal Theoretical \& Applied Science}

p-ISSN: 2308-4944 (print)

e-ISSN: 2409-0085 (online)

Year: 2017

Issue: 08

Volume: 52
Shafa Tiflis Aliyev

Doctor of Economic Sciences, Professor of Sumgait State University, Member of the Expert Council on Economic Sciences the Higher Attestation Commission under the President of the Azerbaijan Republic

Published: $30.08 .2017 \quad$ http://T-Science.org

SECTION 31. Economic research, finance, innovation, risk management.

\title{
PECULIARITIES OF HISTORICAL DEVELOPMENT AND CONTEMPORARY ASPECTS OF THE ECONOMY OF AZERBAIJAN
}

\begin{abstract}
The the features of historical development and modern aspects of the economy of Azerbaijan are explored in the article. The history of the development of the Azerbaijani economy, including during its period of being in the Russian Empire, as an independent Azerbaijan Democratic Republic and in the status of one of the 15 republics of the former USSR is analyzed. The main phases of development of the Azerbaijani economy, primarily the evolution of the oil industry, are considered. The development and role of the oil industry in meeting the needs of the former USSR with fuel, lubricants and gasoline is especially emphasized, especially during the Great Patriotic War to meet the needs of the advanced front. Features of the development of the economy of Azerbaijan after the Great Patriotic War - during the second half of the twentieth century are considered. The special success of the economy of the Azerbaijan SSR during the period 1970-1985 is noted. The peculiarities of the economy of independent Azerbaijan after the restoration of independence in connection with the fall of the former USSR are analyzed. The essence of the ongoing economic reforms, formation and implementation of the model of economic development of Azerbaijan over the past decades is revealed. The reasons for the instability of the Azerbaijani economy in the conditions of falling oil prices in world markets and the expansion of the negative consequences of financial crises in the world are indicated. A number of recommendations and proposals on modernization and strategic development of the national economy of the Republic of Azerbaijan in the near and long term in the context of the growth of global economic threats are generalized and given.

Key words: Azerbaijan, the historical development of the Azerbaijani economy, the evolution and formation of the Azerbaijani economy, the features of the national economy of Azerbaijan, the model of Azerbaijan's economic development, modern aspects of the development of the Azerbaijani economy, the economy of Azerbaijan in the face of growing global economic threats.
\end{abstract}

Language: Russian

Citation: Aliyev ST (2017) PECULIARITIES OF HISTORICAL DEVELOPMENT AND CONTEMPORARY ASPECTS OF THE ECONOMY OF AZERBAIJAN. ISJ Theoretical \& Applied Science, 08 (52): 67-74.

Soi: http://s-o-i.org/1.1/TAS-08-52-10 Doi: crossef https://dx.doi.org/10.15863/TAS.2017.08.52.10

\section{ОСОБЕННОСТИ ИСТОРИЧЕСКОГО РАЗВИТИЯ И СОВРЕМЕННЫЕ АСПЕКТЫ ЭКОНОМИКИ АЗЕРБАЙДЖАНА}

Аннотация: В статье исследованы особенности исторического развития и современные аспекты экономики Азербайджана. Анализирована история развития экономики Азербайджана, в том числе в период бытности его в составе Российской империи, в качестве независимой Азербайджанской Демократической Республики и в статусе одной из 15-ти республик бывтего СССР. Рассмотрены основные фазы развития экономики Азербайджана, прежде всего эволюиия нефтяной промышленности. Особо подчеркнуто развитие и роль нефтяной промышленности в обеспечении потребностей бывщего СССР горючим, смазочными маслами и бензином, особенно в период Великой Отечественной Войнь для обеспечения потребностей передового фронта. Рассмотрены особенности развития экономики Азербайджана после Великой Отечественной войны - в период второй половины ХХ века. Отмечен особый успех экономики Азербайджанской ССР в период 1970-1985 годов. Анализировань особенности экономики уже самостоятельного Азербайджана после восстановления независимости в связи с падением бывшего СССР. Раскрыта сущность проводимых экономических реформ, формирования и осуществления модели 
экономического развития Азербайджана за последние десятилетия. Указаны причины нестабильности экономики Азербайджана в условиях падения ичен на нефть на мировых рынках и расширения негативных последствий финансовых кризисов в мире. Обобщен и дан ряд рекомендаций и предложений по модернизации и стратегическому развитии национальной экономики Азербайджанской Республики в ближайшей и долгосрочной перспективе в контексте роста глобальных экономических угроз.

Ключевые слова: Азербайджан, историческое развитие экономики Азербайджана, эволючия и формирование экономики Азербайджана, особенности национальной экономики Азербайджана, модель экономического развития Азербайджана, современные аспекты развития экономики Азербайджана, экономика Азербайджана в условиях роста глобальных экономических угроз.

\section{Introduction}

Экономика Азербайджана в настоящее время испытывает исторические экзамены в условиях роста негативных последствий глобальных экономических процессов и глобальных угроз. Азербайджан, имея в наличии достаточно природных богатств и экономических ресурсов, поставил перед собой стратегические задачи и цели по вхождению в число экономически развитых и конкурентоспособных стран мира[1; 2]. Отметим, что для этого в Азербайджане имеются все основания, в том числе исторические предпосылки, традиции умения совершенствовать модели экономического развития, универсальные и в то же время конкурентоспособные механизмы нынешней экономической системы страны.

\section{Materials and Methods}

История экономики Азербайджана еще в период бытности Российской империи испытывала серьезные трудности и не имела возможность формирования самостоятельной экономической мысли и подхода[3]. Дело в том, что Азербайджан считался одниой из главных сырьевых баз Российской империи. Начиная с середины XIX века, в России, в том числе в Азербайджане стала развиваться капиталистическая система хозяйственной деятельности, и началось строительство фабрик, заводов[4]. В Азербайджане началось интенсивное развитие нефтяной отрасли, где в 1859 году вблизи города Баку - в Сураханах был построен первый нефтеперерабатывающий завод. В последующие годы один за другими были введены в эксплуатацию парафиновый завод (1861) в Пираллахи, медеплавительный завод в Гедабеке и кобальтовый завод в Дашкесене (1865). Также, в городе Нуха (ныне Шеки), былапостороенадля того периода самая крупная в Европе шелковая фабрика (1861). Таким образом, промышленность Азербайджана стала развиваться сильнее, чем другие отрасли. Особенно отставало сельское хозяйство Азербайджана, где до создания СССР использовались примитивные ручные техника для земледелия и выращивания сельскохозяйственных и бахчевых культур. Уже в начале XX века, наряду с городом Баку в других, более крупных городах Азербайджана (Гянджа, Шуша, Шеки и прочее) были построены десятки заводов и фабрик[5]. Кроме того, стали увеличиваться капитальные вложения в различные сферы промышленности, особенно в пищевую и легкую промышленность, открывались торговые дома. Более того, национальный меценат и предприниматель Гаджи Зейналабдин Тагиев вложил огромные средства в развитие виноделия и виноградарства. Однако негативные последствия промышленного кризиса в начале XXI века замедлили набранные темпы развития промышленности. Уже в это период ускорилась централизация нефтяной промышленности в руках иностранных компаний, больше всего долю имели компания «Братья Нобель» и общество «Мазут». «Братья Нобель» владели $40 \%$ от всей доли нефти, отправленной из Азербайджана в другие страны. Концентрация в руках единичных компаний нефтяной отрасли нанесла огромный урон национальным производителям и предпринимателям нефти и другим промышленным сферам, связанным с нефтью. Большинство мелких и средних предприятий попросту были вынуждены закрываться или, не выдержав конкуренции со стороны монополистов крупных нефтяных компаний, выходили из строя.

В первое 20-тилетие XX века в Азербайджане постепенно сформировалось национальное мышление и понятие национальных экономических интересов. Развивалась национальная буржуазия и капиталистическое общество. Больше всего осозналась необходимость развития потенциальных сфер национальной экономики наряду с нефтяной отраслью. После падения Российской империи, на волне изменений государственного строя и границ в мире, впервые на Востоке, а именно в Азербайджане, образовались Азербайджанская Демократическая Республика. В период создания самостоятельной Республики в Азербайджане серьезно активизировались процессы национального самосознания, в том числе развития экономических мышлений и подходов. К сожалению, сформированная и созданная независимая Азербайджанская Демократическая Республика просуществовала недолго, 
просуществовав всего 23 месяца (с 28 мая 1918 года до 20 апреля 1920 года). В проводимых самостоятельных действиях Демократической Республики особое место занимало развитие регулирования собственности имущества, акционеров муниципальной собственности наряду с государственным имуществом. Пристальное внимание было уделено развитию сельскому хозяйство и сельской местности. Обеспечение сельхозпроизводителей и крестьян землей являлось одним из главных приоритетов экономической политики Республики. Сформировались независимые финансововалютные и налоговые механизмы, развивалась банковская система, стабилизировалось денежное обращение и прочие экономические компоненты государственности. Однако молодая Республика была захвачена большевиками, и Азербайджан был вынужден свыше 70 лет находиться в составе бывшего СССР - советской власти (с 28 апреля 1920 года до 18 октября 1991 года).

В период пребывания в составе СССР, Азербайджан вновь стал нефтяной базой советского союза. Руководство СССР выделяло средства и оборудования для развития нефтяной отрасли. Началась замена старых оборудований нефтяных скважин, и принимались меры по повышению производительности в нефтяной отрасли. В 1920-1939-х годах из общего объема вложенных капитальных средств со стороны руководства СССР в Азербайджан - $65 \%$ отправлялись на развитие промышленного сектора в Азербайджане. А 85 \% из этих средств исключительно направлялись на развитие нефтяной отрасли[6]. Благодаря подобному подходу и политике СССР, перед началом Великой Отечественной Войны, получил серьезные возможности для обеспечения себя и прежде всего нужды армии передового фронта горючим, смазочными маслами и бензином для истребителей. Уже в начале войны общий объем добычи нефти в Азербайджане набрал рекордные тенденции и, по итогам 1941 года, добыча нефти составила 23,5 млрд. тонн. В период войны, благодаря исключительной важной роли Бакинской нефти армия СССР имела преимущество над врагом по надежности обеспеченности горючим и бензином. В период войны Азербайджан обеспечил СССР 71,4% нефти от обще добытой нефти. С целью обеспечения потребности всего СССР по нефти, смазочному материалу и бензину за период войны было произведено 75 млн. тонн нефти и 22 млн. тонн бензина, а также другие нефтепродукты. Азербайджанский ученыйакадемик Юсиф Мамедалиев разработал новейший высокооктановый бензин и ряд смазочных масел.
Только под конец начала Великой Отечественной Войны было осознана необходимость развития других отраслей экономики Азербайджана наряду с нефтяной промышленностью и начались созидательные работы по развитию металлургической, химической и энергетической отрасли экономики Азербайджанской Республики. Были сданы в эксплуатацию крупные предприятия союзного значения. А в 1949 году была добыта первая нефть в открытом море Каспийского шельфа Азербайджана. Стали развиваться тяжелые промышленные сектора, и в результате в последующие десятилетия были образованы два крупных промышленных и энергетических центров в Азербайджане. Город Сумгайыт стал одним из крупных химических и нефтехимических, одновременно промышленных центров не только в Азербайджане, но в целом в СССР. А город Мингечаур стал энергетическим центром, где была создана мощная инфраструктура и производственная база для выработки электроэнергии и т.д. Однако рассвет и интенсивное развитие ненефтяных секторов экономики Азербайджана наступил в период 1970-1985 годов. В это период, благодаря титаническим усилиям руководства Азербайджана - общенационального лидера Гейдара Алиева были полностью модернизированы основные фонды промышленности Республик[7]. Построены новые крупные заводы, в том числе нефтеперерабатывающие, газоперерабатывающие крупные установки, кондиционерный завод (в те времена являлся единственным в СССР), предприятия химии и нефтехимии, металлургические отрасли, приборостроеня, электромеханики, легкой и пищевой промышленности, агросектора и т.д. Отметим, что до 1970 годов в Азербайджане были построены 146 крупных промышленных предприятий, и все они считались союзного значения. Доля города Баку за это период в промышленности была примерно $73 \%$. А в период с 1970 по 1985 годы в Азербайджане по всем основным видам объем производимой промышленной продукции, сельскохозяйственных культур, технических растений выросли в несколько раз. Общий объем промышленной продукции вырос в 2,9 раз, машиностроение в 5,9 раз, химия и нефтехимия 3,1 раза и пищевая период в экономику Азербайджанской Республики промышленность в 4 раза[8; 9]. За это было вложено свыше 40 млрд. долл. США. Все эти крупномасштабные мероприятия способствовали созданию многоотраслевой структуры экономики Республики и доведения до минимума его 
зависимости от топливного сектора, то есть от нефти и газа (см. Рис. 1).

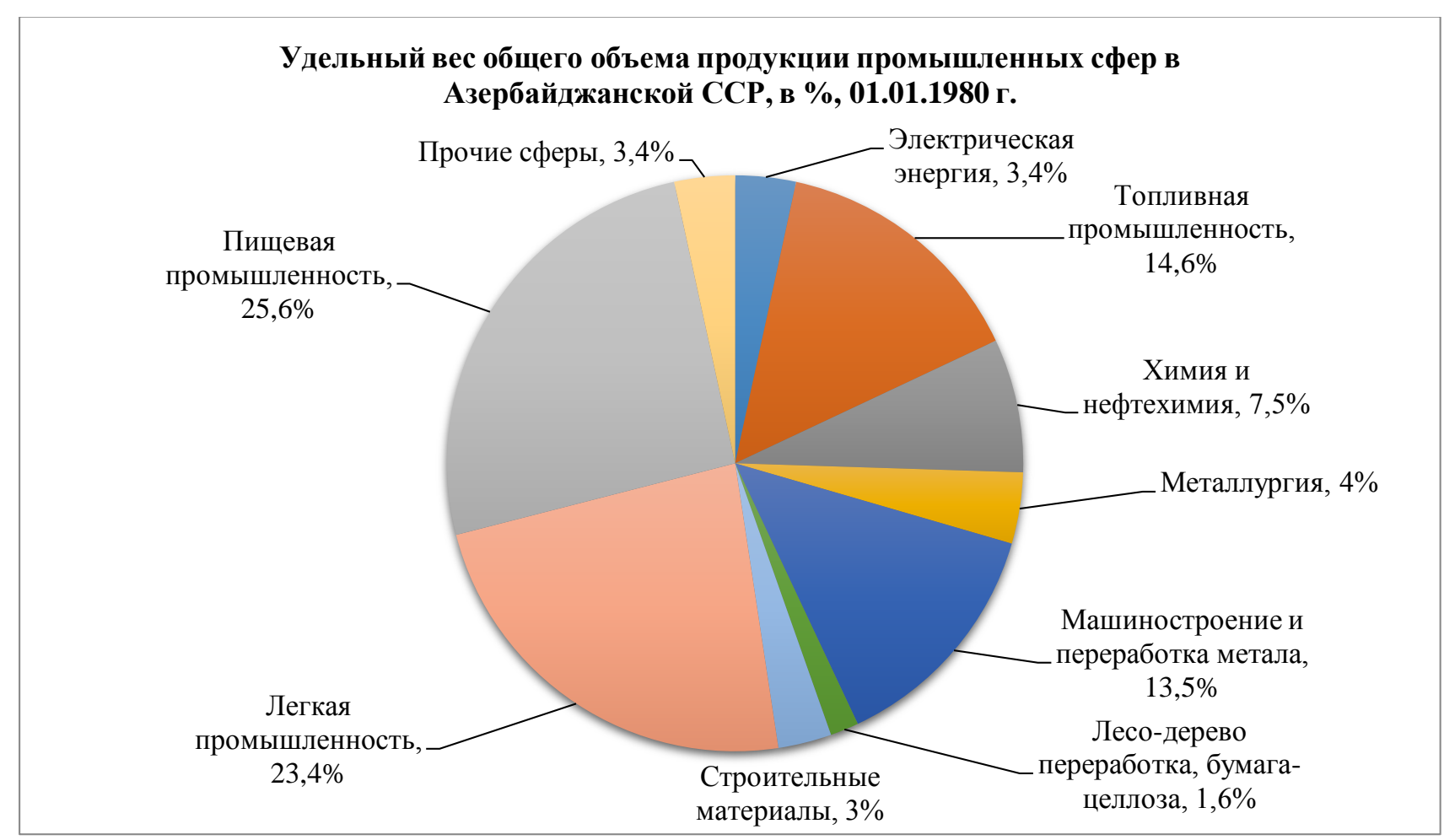

Рисунок 1 - Удельный вес общего объема продукции промышленных сфер Азербайджанского ССР, в \%, 01.01.1980 г.(подготовлено автором).

Если обратить внимание на Рисунок 1, то ясно видно, что самая большая доля в общем объеме продукции промышленной сферы Азербайджанской Республики на 01.01.1980 года принадлежала пищевой промышленности - 29,9 $\%$, далее легкая промышленность - 23,4 \% и только после этого следовала топливная промышленность (куда входит нефть и газ) - 14,6 $\%$, машиностроение и переработка метала - 13,5 $\%$ и т.д.

К большому сожалению, в дальнейшем экономика Азербайджана испытывала огромные трудности и после падения СССР основные базовые отрасли экономики Республики подвергались серьезному кризису, краху и хаосу. Уже в начале 1990-х годов, в первые годы после восстановления независимости

Азербайджанской Республике, экономике страны потребовалась фундаментальное преобразование и создание новой экономической системы и механизмов с учетом независимости и перехода на рыночную экономику. Долгие годы экономика Азербайджана испытывала трудности из-за недостаточных финансовых средств для проведения основных фаз экономических реформ и создание инфраструктуры национальной экономики. Только с реализацией нефтяной стратегии и обновлением современных технологий нефтяная отрасль страны началась развиваться с проведением экономической реформы. За период с 1994 по 2003 годы были полностью завершены основные процессы экономических реформ и институциональных преобразований, построены сотни современных инфраструктурных объектов и сооружений, обновлены механизмы экономической политики[10; 11; 12; 13; 14]. Из-за роста нефтяных цен на мировом рынке за 2003 по 2008 годы Азербайджану удалось выручить немалые валютные средства и довести свои валютные резервы до 50 млрд. долл. США. Обеспечение финансовой стабильности и макроэкономического благополучия помогло молодому государству проводить активную экономическую политику по улучшению благосостояния населения страны и модернизации своей модели экономического развития с учетом требований нынешнего времени. Однако с началом финансового кризиса в мире Азербайджан снова стал перед экзаменом под влиянием глобальных экономических тенденций и экономических угроз[15; 16]. Молодая экономика Азербайджана во многом выдержала негативные последствия глобальных изменений, но после неоднократных падений цен на нефть на мировом рынке в 2014-2015 годы 


\begin{tabular}{|c|c|c|c|c|c|c|}
\hline Impact Factor: & $\begin{array}{l}\text { ISRA (India) } \\
\text { ISI (Dubai, UAE } \\
\text { GIF (Australia) } \\
\text { JIF }\end{array}$ & $\begin{array}{r}=1.344 \\
=0.829 \\
=0.564 \\
=1.500\end{array}$ & $\begin{array}{l}\text { SIS (USA) } \\
\text { PИHЦ (Russia) } \\
\text { ESJI (KZ) } \\
\text { SJIF (Morocco) }\end{array}$ & $\begin{array}{l}=\mathbf{0 . 9 1 2} \\
=\mathbf{0 . 2 0 7} \\
=\mathbf{3 . 8 6 0} \\
=\mathbf{2 . 0 3 1}\end{array}$ & $\begin{array}{l}\text { ICV (Poland) } \\
\text { PIF (India) } \\
\text { IBI (India) }\end{array}$ & $\begin{array}{l}=6.630 \\
=1.940 \\
=4.260\end{array}$ \\
\hline
\end{tabular}

страна испытывала серьезные трудности и в начале 2015 года подверглась девальвации и в течение года национальная валюта страны потеряла свою стоимость почти в 2 раза. В связи с этим, Азербайджану потребовалась глубокая модернизация модели экономического развития, разработка и внедрение более продуктивных и прочных механизмов развития национальной экономики, отвечающих требованиям антикризисных условий. Определилась и началась реализация стратегических целей и задач в рамках стратегической карты Азербайджана по перспективам развития национальной экономики в ближайшей и долгосрочной перспективе[17; 18; 19]. На Рисунке 2 дана динамика объема ВВП Азербайджанской Республики за 2011-2016 годы.

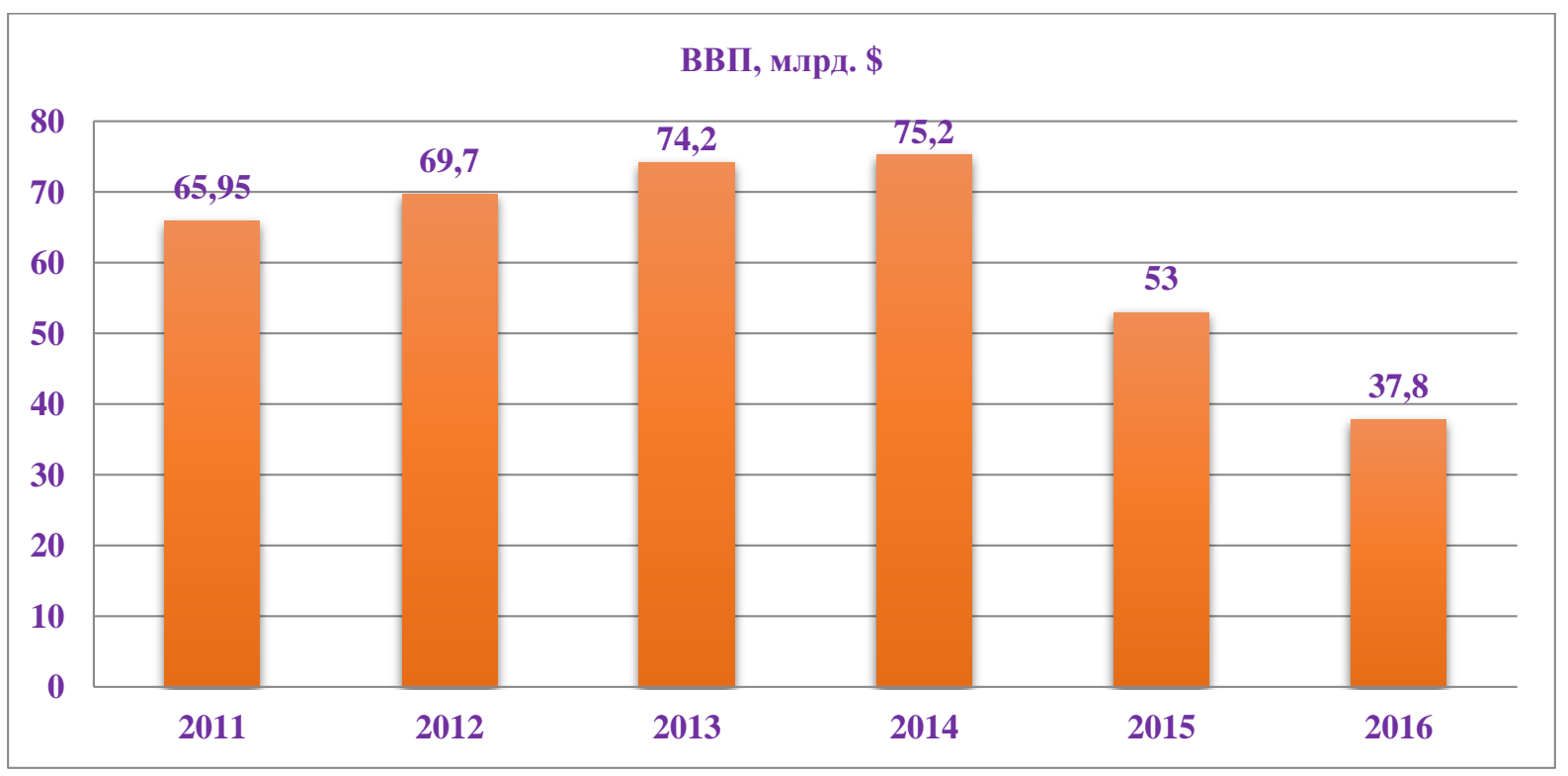

Рисунок 2 - Динамика объема ВВП Азербайджанской Республики за 2011-2016 годы, млрд. \$. (подготовлено автором).

Если анализировать Рисунок 2 и экономические показатели Азербайджана, то видно, что за 2015 и 2016 годы ВВП Азербайджана в долларной стоимости резко упала и в 2016 году падения уровня ВВП по отношению к 2014 году составила разницу почти в 2 раза[20; 21]. Это связано, как было отмечено ранее, с падением курса национальной валюты Азербайджана за последние годы. На Рисунке 3 приведена динамика роста ВВП в Азербайджана в \%-тах уже к предыдущему году.

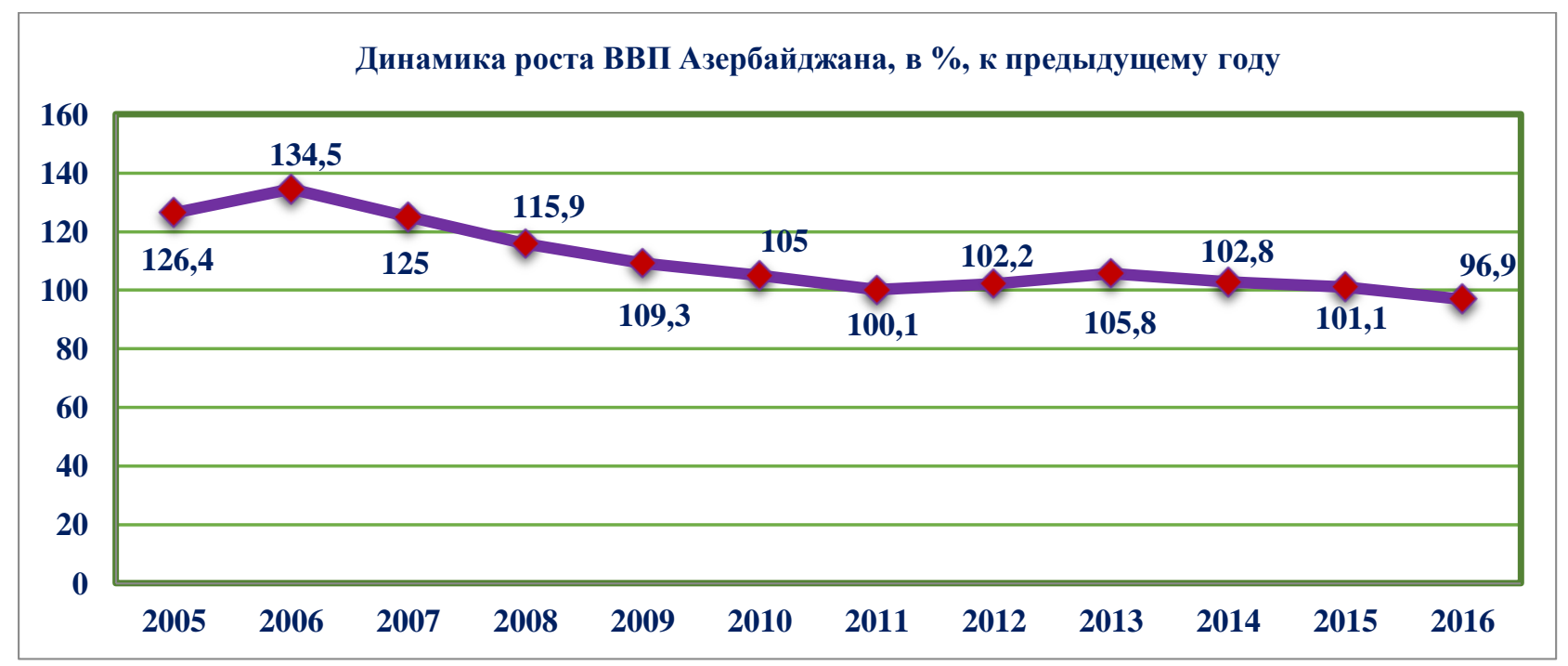

Рисунок 3 - Динамика роста ВВП Азербайджана, в \%, к предыдущему году (подготовлено автором).

ISPC Technology and Innovation,

Philadelphia, USA 


\begin{tabular}{|c|c|c|c|c|c|c|}
\hline Impact Factor: & $\begin{array}{l}\text { ISRA (India) } \\
\text { ISI (Dubai, UAE } \\
\text { GIF (Australia) } \\
\text { JIF }\end{array}$ & $\begin{array}{r}=1.344 \\
=0.829 \\
=0.564 \\
=1.500\end{array}$ & $\begin{array}{l}\text { SIS (USA) } \\
\text { PИHЦ (Russia) } \\
\text { ESJI (KZ) } \\
\text { SJIF (Morocco) }\end{array}$ & $\begin{array}{l}=\mathbf{0 . 9 1 2} \\
=\mathbf{0 . 2 0 7} \\
=\mathbf{3 . 8 6 0} \\
=\mathbf{2 . 0 3 1}\end{array}$ & $\begin{array}{l}\text { ICV (Poland) } \\
\text { PIF (India) } \\
\text { IBI (India) }\end{array}$ & $\begin{array}{l}=6.630 \\
=1.940 \\
=4.260\end{array}$ \\
\hline
\end{tabular}

Анализ Рисунка 2 и 3 обуславливает необходимость обеспечения устойчивого и продуктивного развития национальной экономики Азербайджана, обеспечения его динамичного роста и формирования новых надежных источников по созданию добавочной стоимости экономики страны. На Рисунке 4 дана динамика ВВП на душу населения в Азербайджанской Республике за 2011-2016 годы.

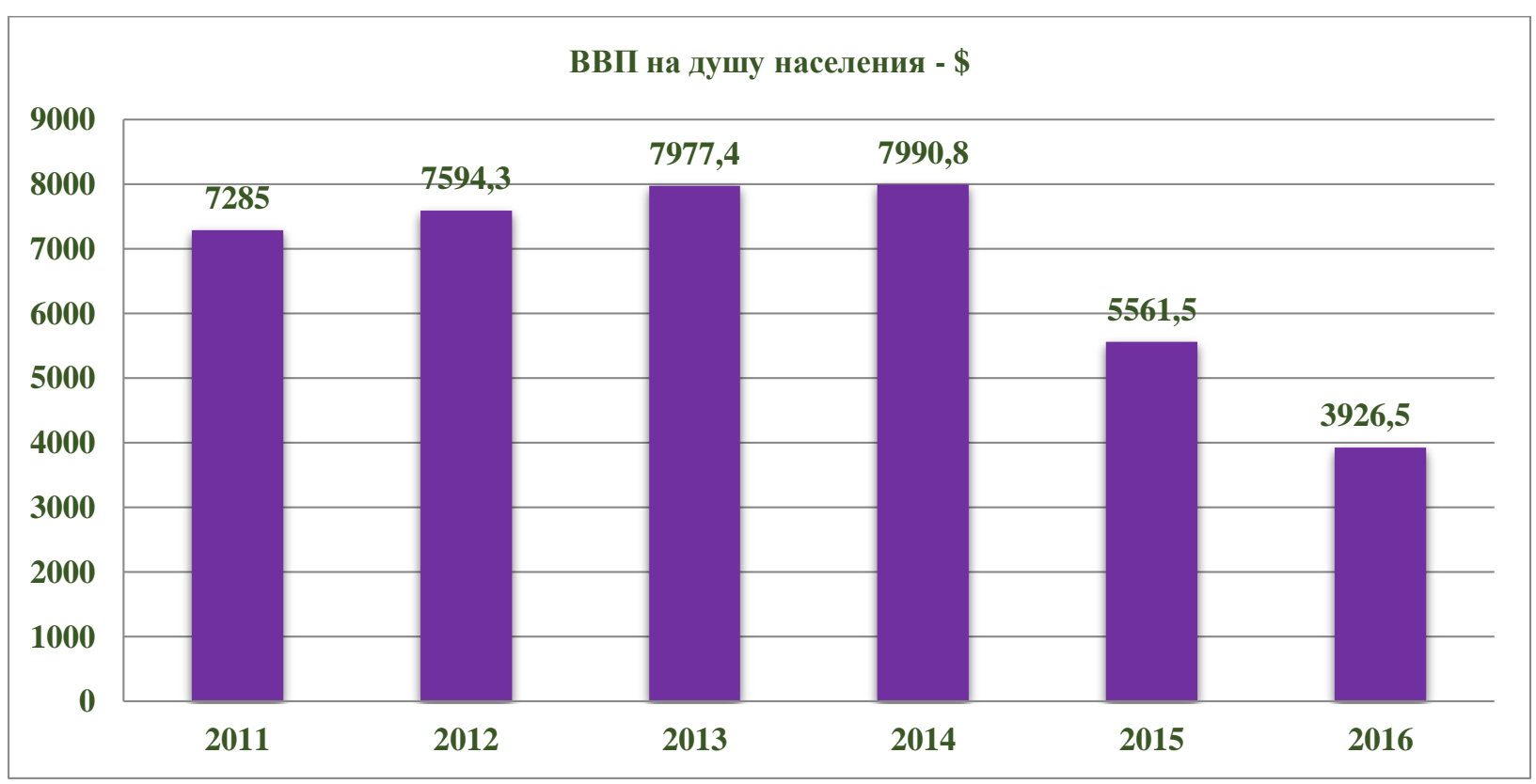

Рисунок 4 - ВВП на душу насления в Азербайджанской Республике за 2011-2016 годы (подготовлено автором).

Анализ Рисунка 4 показывает, что падение общего объема ВВП в долларовой стоимости за последние два года оказало аналогичное отрицательное влияние и на динамику ВВП на душу населения. В 2016 году объем ВВП на душу населения составил почти 3927 долл. США и это в 2 раза меньше, чем показатели в 2013 и 2014 годах.

Для роста экономики Азербайджана и минимизации его развития от нефтяного сектора требуется ускорение расширения деятельности ненефтяных секторов экономики и особенно обеспечение роста ВВП ненефтяного сектора и тем самым создать благоприятные условия роста национальной экономики. За период 2006-2014 годов рост ВВП ненефтяного сектора Азербайджана вырос почти в 5 раз, однако начиная с 2015 года, динамика ВВП ненефтяного сектора страны в долларовой стоимости демонстрирует тенденцию снижения[22]. Данные, отраженные на Рисунке 5 показывают снижение ВВП нефтяного сектора более конкретно, уже начиная с 2015 года (см. Рис. 5.). 


\begin{tabular}{|c|c|c|c|c|c|c|}
\hline Impact Factor: & $\begin{array}{l}\text { ISRA (India) } \\
\text { ISI (Dubai, UAE } \\
\text { GIF (Australia) } \\
\text { JIF }\end{array}$ & $\begin{array}{r}=1.344 \\
=0.829 \\
=0.564 \\
=1.500\end{array}$ & $\begin{array}{l}\text { SIS (USA) } \\
\text { PИНЦ (Russia) } \\
\text { ESJI (KZ) } \\
\text { SJIF (Morocco) }\end{array}$ & $\begin{array}{l}=0.912 \\
=\mathbf{0 . 2 0 7} \\
=\mathbf{3 . 8 6 0} \\
=\mathbf{2 . 0 3 1}\end{array}$ & $\begin{array}{l}\text { ICV (Poland) } \\
\text { PIF (India) } \\
\text { IBI (India) }\end{array}$ & $\begin{array}{l}=6.630 \\
=1.940 \\
=4.260\end{array}$ \\
\hline
\end{tabular}

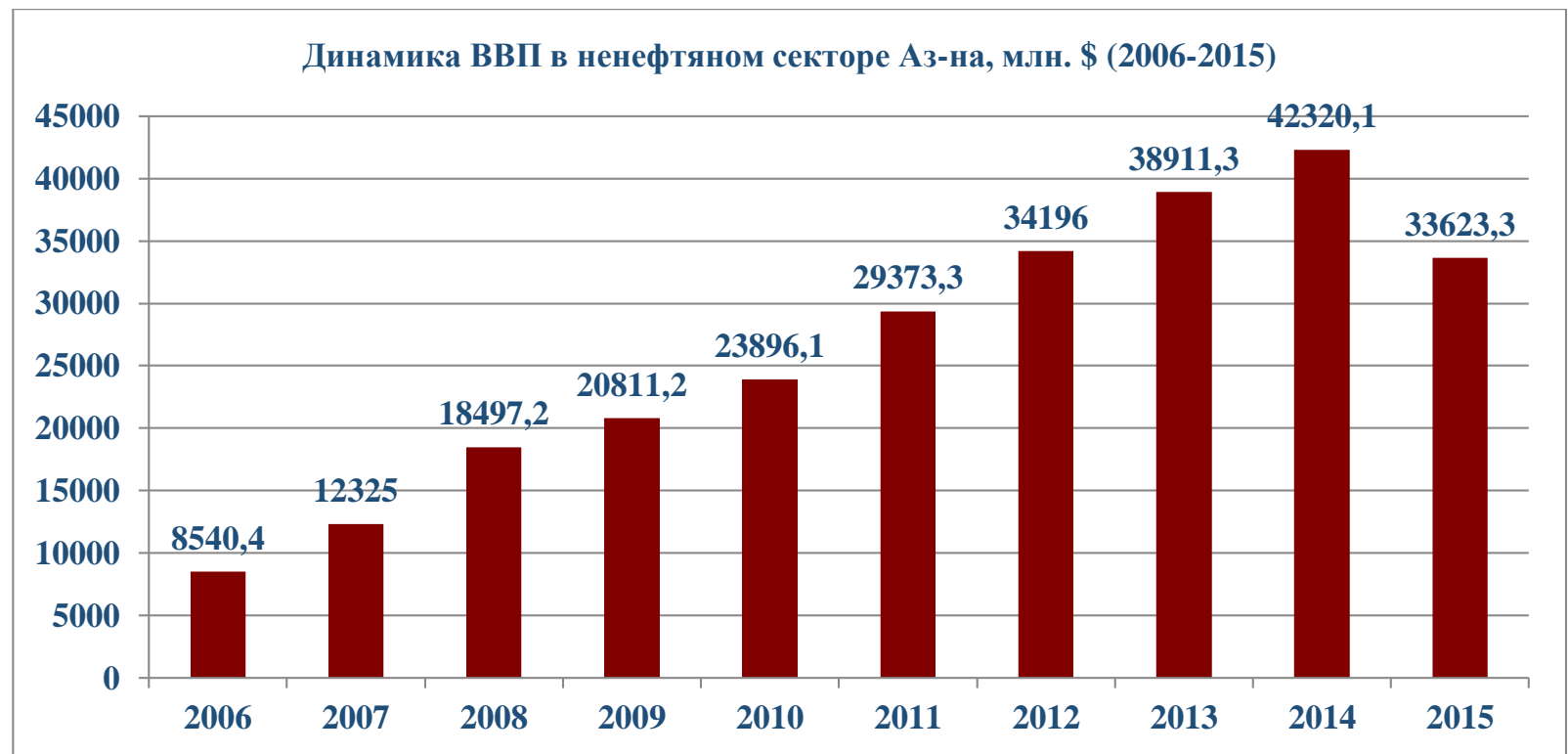

Рисунок 5 - Динамика ВВП в ненефтяном секторе Азербайджаснкой Республики, млн. долл. (подготовлено автором).

Проблемы

макроэкономической стабильности и замедление темпа роста национальной экономики требуют ускоренного развития, прежде всего, промышленного сектора страны, который играет важное значение в обеспечении роста экономики и создания добавочной стоимости для национальной экономики. На Рисунке 6 дан объем промышленной продукции в Азербайджане за период 2006-2016 годов.

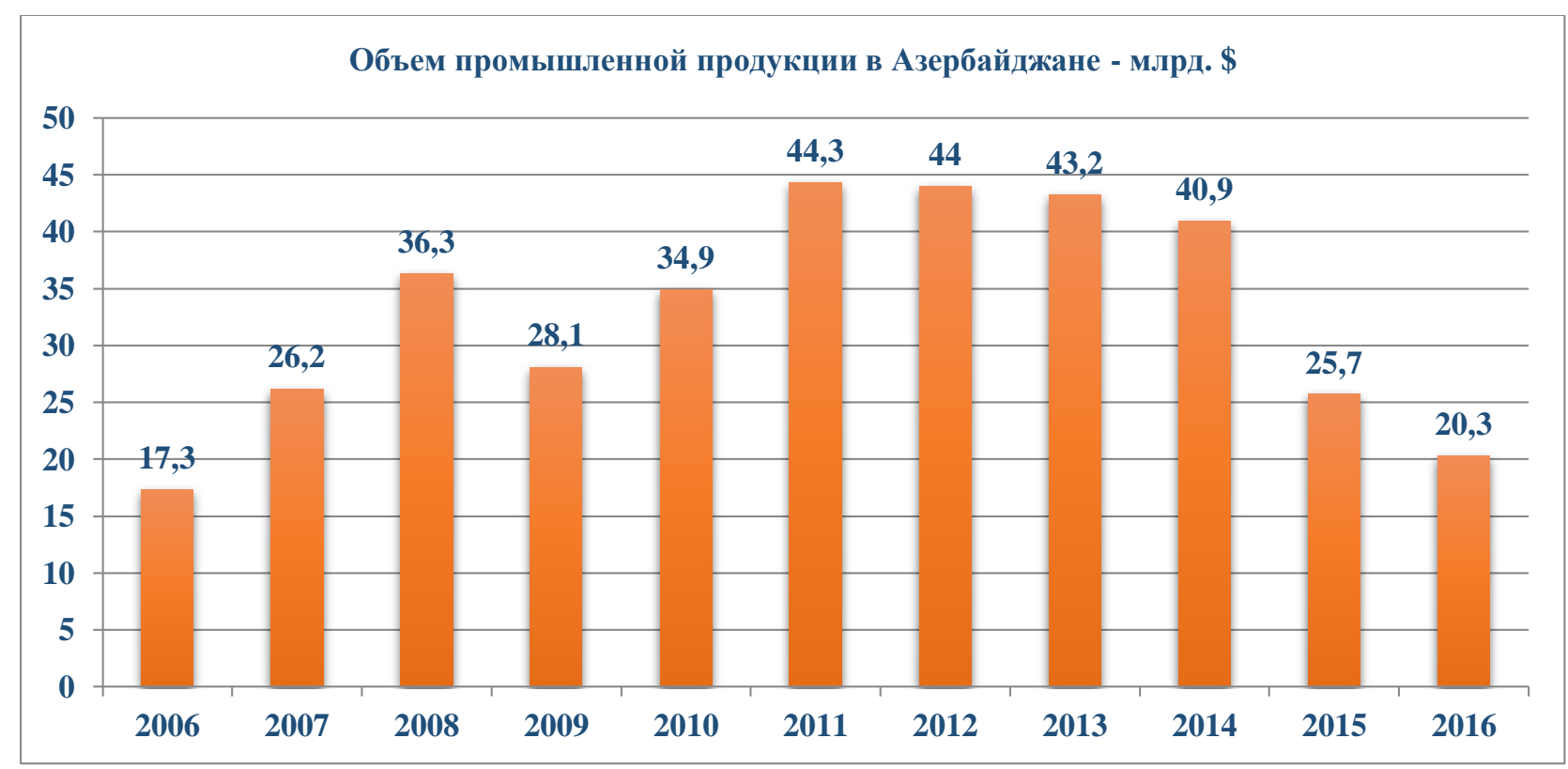

Риснок 6 - Объем промышленной продукции в Азербайджанской Республике за 2006-2016 годы, млрд. долл. (подготовлено автором).

Анализ Рисунка 6 показывает, что начиная с 2011 года в долларовой стоимости, объем промышленной продукции Азербайджана демонстрирует тенденцию снижения. И в 2016 году уровень снижения общего объема промышленной продукции по отношению к 2011 году составил 2,18 раз.

\section{Conclusion}

Обобщая вышеприведенные анализы современное состояние экономики Азербайджана 
можно придти к выводу, что в ближайшей перспективе необходимо принимать кардинальные изменения в структуре и механизмах модели экономического развития Азербайджана. Современные аспекты и особенности макроэкономических проблем, проблемы роста экономики и повышения его устойчивости в условиях антикризисных влияний и роста негативных последствий глобальных экономических угроз обуславливают максимальное совершенствования структуры национальной экономики, обеспечивают его саморазвитие, обновление основных механизмов и практичных инструментарий по созданию продуктивной добавочной стоимости национальной экономики и повышенияее конкурентоспособности и т.д.

\section{References:}

1. (2016) Strategicheskiye dorozhnyye karty po perspektivam natsional'noy ekonomiki Azerbaydzhanskoy Respubliki.Utverzhdeno Ukazom Prezidenta Azerbaydzhanskoy Respublikiot 6 dekabrya 2016 goda.

2. (2012) Kontseptsiirazvitiya "Azerbaydzhan2020: vzglyad v budushcheye" (29.12.2012).

3. (2008) Istoriya Azerbaydzhana. V 7-mi tomakh.V tom (1900-1920 gg.). Baku, «Nauka», 2008.-696 p.

4. Sumbatzate A.S. (1964) Promyshlennost' Azerbaydzhana v XIX v. Baku.

5. (2017) Ekonomika Azerbaydzhana s periodaserediny XIX veka do padeniyabyvshego SSSR. Prezidentskaya biblioteka. www.files.preslib.az.

6. Samedzade Z.A. (1980) Struktura i effektivnost' obshchestvennogo proizvodstva (na materialakh Azerbaydzhanskoy SSR). Baku, Izdatel'stvo «Elm», 1980.-208 p.

7. Akhundova E. (2007) GeydarAliyev. Lichnost' i epokha.Chast' II.(1969-1982). «Ozan», 2007.$840 \mathrm{p}$.

8. Aliyev SH.T. (2012) Otsenki khimicheskogo i nfetekhimichskogo kompleksa Azerbaydzhana i napravleniye modernizatsii Baku, «Nauka i obrazovaniye», 2012.-156 p.

9. Aliyev SH.T. (2012) Sumgayytskiy promyshlennyyt sentr: ispol'zovaniye sushchestvuyeshchego potentsiala, prioritety modernizatsii i obnovleniye, Baku, «Nauka i obrazovaniye», 2012.-196 p.

10. Mekhtiyev R.A. (2005) Azerbaydzhan: trebovaniya $\mathrm{v}$ period globalizshchatsii. Baku: XXI vek. Dom NovykhIzdaniy, 2005.-464 p.

11. Nuriyev A.KH. (2013) Kontseptual'nyye osnovy politiki modernizatsii i ekonomicheskogo razvitiya $\mathrm{v}$ Azerbaydzhane. Baku, «AVRORA», 2013.-422 p.

12. Shakaraliyev A., Shakaraliyev G. (2016) Ekonomika Azerbaydzhana: realii $\mathrm{i}$ perspektivy. Baku, «Turkhan», NPV, 2016.-536 p.

13. Aliyev U.G. (2008) Natsional'nyye ekonomicheskiye problemi perekhodnogo perioda. Monografiya.Baku: Azerneshr, 2008.$358 \mathrm{p}$.

14. Gasanov R.T. (2012) Osobennosti sotsial'noekonomicheskogo razvitiya sovrmennogo Azerbaydzhana // Nalogovyy zhurnal Azerbaydzhana, №2, 2012.-p.103-108.

15. Gambarov F.A. (2014) Vneshneekonomicheskiye factory obespecheniya ekonomicheskogo rosta V Azerbaydzhane v usloviyakh globalizatsii Avtoreferat diss. D-raekon.nauk. Baku, 2014.$60 \mathrm{p}$.

16. Guseynov T. (2015) Natsional'naya model' ekonomicheskogorazvitiyaAzerbaydzhana: teoriya i praktika. Monografiya.Baku, 2015.$460 \mathrm{p}$.

17. Aliyev SH.T. (2017) Puti povysheniya eksportnogo potentsiala $\mathrm{v}$ realizatsii Strtayegicheskikh dorozhnykh kart v Azerbaydzhane // Zhurnal Audit № 1, 2017. -p. 60-66.

18. Aliyev SH.T. (2015) Vneshne ekonomicheskaya politika Azerbaydzhana. Izdatel'stvo Sumgayyskogo Gosudartsvennogo Universiteta 2015.-185 p.

19. Aliyev SH.T. (2015) Tekhnoparki budut usilivat' promyshlennyy i eksportnyy potentsial Azerbaydzhana. Azerbaydzhan-2015.-12 aprelya.-p.9. http://www.anl.az.

20. Natsional'nyye scheta Azerbaydzhana. Statisticheskoye izdaniye.Baku, 2016.-181 s.

21. Ekonomicheskiye pokazateli Azerbaydzhana. Baku, 2016 .-824 s.

22. Azerbaydzhan v tsifrakh, 2017. Baku, 2017.286 s. http//:www.azstat.org. 